\title{
Monoclonal antibody specific to HA2 glycopeptide protects mice from H3N2 influenza virus infection
}

\author{
Xing Xie, Yan Lin, Maoda Pang, Yanbing Zhao, Dildar Hussain Kalhoro, Chengping Lu and Yongjie Liu*
}

\begin{abstract}
Canine influenza virus (CIV) subtype H3N2 is a newly identified, highly contagious respiratory pathogen that causes cough, pneumonia and other respiratory symptoms in dogs. Data indicate that the virus is responsible for recent clinical cases of dog disease in China. However, therapeutic options for this disease are very limited. In this study, seven monoclonal antibodies (mAbs) against CIV JS/10 (an H3N2 subtype virus) were produced and characterized. Among them, mAb D7, which is specific for the HA2 glycopeptide (gp), induced the highest neutralization titers. The protection provided by mAb D7 was evaluated in BALB/c mice challenged with homologous or heterologous strains of H3N2 influenza virus, including two strains of CIV and one strain of swine influenza virus (SIV). The data show that mAb D7 protected the mice from infection with the three viral strains, especially the homologous strain, which was indicated by the recovery of body weight, reduction of viral load, and reduction of tissue damage. Moreover, the levels of IFN- $\gamma$ and TNF-a in the lungs, as detected by ELISA, were reduced in the infected mice treated with the mAb D7 compared with those without mAb D7 treatment. Thus, our findings demonstrate, for the first time, that a mAb could reduce the release of IFN- $\gamma$ and TNF- $a$ associated with tissue damage by CIV infection and that the mAb might be of great therapeutic value for CIV infection.
\end{abstract}

\section{Introduction}

Influenza A virus, a highly contagious pathogen, can infect both birds and mammals. It has undergone significant genetic variation to adapt to different hosts [1]. Its interspecific transmission is achieved by the recombination or direct transfer of genetic material [2]. The first case of dog infection with H3N8 canine influenza virus (CIV) was reported in the USA in 2004 [3,4], followed by a report of CIV in South Korea, which subsequently demonstrated that CIV was able to transmit directly from dog to dog [5,6]. Recently, the first case of H3N2 CIV infection was reported in Guangdong Province in 2010 [7]. Over recent years, infection with H3N2 CIV in dogs has developed from scattered cases to wide distribution across the country [8-10]. Dogs have no natural immunity to this virus, thus a number of preventive and therapeutic measures against CIV have been attempted to control the prevalence of this virus. Among them, vaccination is an important method to prevent and control influenza virus infection [11-13]. Current vaccine

\footnotetext{
* Correspondence: liuyongjie@njau.edu.cn

College of Veterinary Medicine, Nanjing Agricultural University, Nanjing,
} China

\section{Biomed Central}

research against CIV has made some progress. In 2009, the U.S. Department of Agriculture (USDA) approved a list of vaccines against H3N8 CIV, which could effectively reduce viral shedding [14]. In 2012, the patent for an H3N2 CIV vaccine in South Korea was also approved [15]. Preventive vaccination is historically the primary measure to control influenza virus infection, but it has some limitations [16]. For example, influenza vaccines may not be effective enough to prevent against divergent viral strains, or may be less immunogenic and effective in certain groups, such as the very young, the old, and the immunocompromised [17]. Therefore, it is crucial to develop other measures to protect animals from infection/disease [18]. For example, passive immunity by transferring a specific antibody to a recipient could protect animals from infection [19]. Monoclonal antibodies (mAbs) can neutralize viruses, thus preventing virus attachment to, or fusion with, the host cell [20]. Many studies have demonstrated that mAbs are an effective and preventive treatment against human-origin [21-23] or avian-origin influenza virus infection $[11,24,25]$. However, to date, there are no neutralizing mAbs available to prevent and control H3N2 CIV infection. 
In this study, we identified seven mAbs against H3N2 $\mathrm{CIV}$, and tested one of them, the D7 mAb, against three different H3N2 subtype virus strains in animal experiments. This is the first description of a neutralizing $\mathrm{mAb}$ against H3N2 CIV.

\section{Materials and methods}

Virus strains, cells and medium

Three viral strains of the H3N2 subtype, including A/ Canine/Jiangsu/06/2010 (JS/10), A/Canine/Guangdong/ 12/2012 (GD/12) and A/swine/Shandong/3/2005 (SD/05) were used in this study. The GenBank accession numbers of JS/10, GD/12 and SD/05 are JN247616 to JN247623, KF826944 to KF826951 and EU116037 to EU116044, respectively. The three viral strains were adapted to mice by passaging 3 times. They were propagated in 10-day-old specific-pathogen free (SPF) embryonated chicken eggs and stored at $-70^{\circ} \mathrm{C}$ before use.

Madin-Darby canine kidney (MDCK) cells were cultured in Dulbecco's modified essential medium (DMEM) containing $10 \%(\mathrm{v} / \mathrm{v})$ fetal bovine serum (Hyclone, tah, USA) and maintained at $37{ }^{\circ} \mathrm{C}$ and in a $5 \%(\mathrm{v} / \mathrm{v}) \mathrm{CO}_{2}$ atmosphere.

\section{Experimental animals}

BALB/c mice (6 weeks old, female) were purchased from the Animal Experiment Center, Yangzhou University. All animal experiments complied with the guidelines of the Animal Welfare Council of China, and the Animal Ethics Committee of Nanjing Agricultural University approved the study.

Fifty-percent tissue culture infective dose $\left(\mathrm{TCID}_{50}\right)$ assays One day before infection, a 96-well dish containing a monolayer of MDCK cells was prepared. The next day, serial dilutions of the three influenza virus strains were made, and the cell monolayers were laterally inoculated; each dilution had three replicates. The cytopathic effect (CPE) was observed daily and the numbers of wells for a virus dilution that showed more than and less than $50 \%$ pathological changes were recorded. $\mathrm{TCID}_{50}$ titers were calculated in accordance with the Reed-Muench method [26].

\section{Generation of H3N2 mAbs}

Canine influenza virus JS/10 was grown in 10-day-old SPF embryonated chicken eggs at $37{ }^{\circ} \mathrm{C}$ for $72 \mathrm{~h}$. Allantoic fluids were harvested and the hemagglutination (HA) activity of the allantoic fluids was tested at room temperature using $1 \%$ chicken red blood cells (RBC). HA titers more than or equal to 1:64 were selected, and the virus was purified using differential centrifugation and sucrose density gradient centrifugation. Preparation of anti-H3 mAbs followed standard hybridoma technology, as previously described [27]. Six-week-old female BALB/c mice were injected intracutaneously with $100 \mu \mathrm{g}$ of purified virus JS/10 using complete Freund's adjuvant (Sigma, Beijing, China) as the primary adjuvant, followed by incomplete Freund's adjuvant. Three days before harvesting the splenocytes, $100 \mu \mathrm{g}$ of JS/10 were inoculated intravenously. Isolation and screening of the hybridomas was performed as described previously [28]. MAbs were prepared by injecting hybridoma cells into the peritoneal cavities of pristane-primed $\mathrm{BALB} / \mathrm{c}$ mice. The ascetic fluid was collected after 9-12 days and inactivated at $56{ }^{\circ} \mathrm{C}$ for $30 \mathrm{~min}$.

\section{Hemagglutination inhibition ( $\mathrm{HI}$ ) and microneutralization tests}

The HI test was performed to assess antibody reactivity against three H3N2 strains, JS/10, GD/12 and SD/05, as previously described [29]. Briefly, $25 \mu \mathrm{L}$ of serial twofold dilutions of the purified 5-fold diluted ascetic fluid of the mAb were mixed with 4 HA units of virus in disposable hemagglutination plates and incubated at $37{ }^{\circ} \mathrm{C}$ for $30 \mathrm{~min}$. Then, $25 \mu \mathrm{L}$ of $1 \%$ chicken $\mathrm{RBC}$ were added to each well and incubated at room temperature for 30 min. To rule out non-specific inhibition, in the HI assay, we used the ascetic fluid produced with the injection of SP2/0 myeloma cells as a negative control. The HI titer was expressed as the reciprocal of the highest serum dilution that completely inhibited hemagglutination of 4 HA units of the virus [30].

Cell-based neutralization assays were performed as previously described [31]. A dose of $100 \mathrm{TCID}_{50}$ of viruses was used in the assays. Supernatants of ascites were tested at a starting dilution of 1:25. Briefly, two-fold dilutions of hybridoma supernatants were mixed with virus suspension containing $100 \mathrm{TCID}_{50}$ of purified H3N2 virus and incubated at $37{ }^{\circ} \mathrm{C}$ in a $5 \% \mathrm{CO}_{2}$ incubator for $1 \mathrm{~h}$ before their addition to a monolayer of MDCK cells in 96-well plates. One hundred microliters of serum-free DMEM was added to each well and incubation at $37{ }^{\circ} \mathrm{C}$ continued for $1 \mathrm{~h}$. The cytopathic effect was observed every $24 \mathrm{~h}$ for 48 to $72 \mathrm{~h}$.

\section{Antigen identification of MAbs}

To determine the recognized HA domain of the MAbs, we recombinantly expressed the HA, HA1 and HA2 proteins of virus $J S / 10$. The recombinant proteins were subjected to SDS-PAGE under reducing conditions. The proteins were then electro-transferred and immobilized on a nitrocellulose membrane. The membrane was blocked with $5 \%$ nonfat milk in phosphate buffered saline (PBS) containing $0.1 \%$ Tween 20 (PBST) at $37{ }^{\circ} \mathrm{C}$ for $1 \mathrm{~h}$. The membrane was subsequently incubated with the mAb prepared in this study, rinsed in PBST, and incubated with horseradish peroxidase (HRP)-conjugated rabbit anti-mouse immunoglobulin (Bio-Rad, Shanghai, 
China), followed by incubation with chromogenic reagents (Tiangen, Beijing, China) [32].

\section{Cross-protection by $\mathrm{H} 3$-specific $\mathrm{mAb}$}

$\mathrm{BALB} / \mathrm{c}$ mice were used to determine the protective efficacy of mAb D7. Intranasal inoculations with $10^{7}$ TCID $_{50}$ of virus strains $\mathrm{JS} / 10, \mathrm{GD} / 12$ and $\mathrm{SD} / 05$ were given to experimental groups I $(n=45)$, II $(n=45)$ and III $(n=45)$, respectively; the control group received PBS $(n=15)$. Each experimental group was divided into three subgroups ( $n=15$ for each subgroup), which were the virus-infected, mAb D7 and irrelevant mAb IgG subgroups, respectively. Mice injected with PBS or irrelevant $\mathrm{mAb}$ IgG were considered as blank and negative controls, respectively. For the $\mathrm{mAb} \mathrm{D} 7$ and irrelevant $\mathrm{mAb}$ IgG subgroups, mice were pretreated intraperitoneally with mAb D7 $(36 \mu \mathrm{g} / \mathrm{mL})$ or irrelevant mAb IgG $(32 \mu \mathrm{g} / \mathrm{mL})$ against IgM from Chinese breams developed in our laboratory, at a dose of $20 \mathrm{mg}$ per $\mathrm{kg}$ of body weight in $100 \mu \mathrm{L}$ of PBS before the viral challenge $[24,33,34]$. After $24 \mathrm{~h}$, mice were challenged with three different H3N2 strains. Mice were observed daily to monitor body weight and clinical symptoms for up to 14 days.

Three mice from each subgroup were euthanized humanely according to a pre-designated schedule. At 2, 4, 6, 10 and 14 days post-infection (dpi), blood samples and tissues including heart, spleen, lung, brain and intestine, as well as feces were collected. Virus shedding was detected by screening fecal samples. Detection of viral RNA was used to determine tissue distribution and virus shedding. Tissues and feces were homogenized in lysates at a ratio of $1: 1(\mathrm{~g} / \mathrm{mL})$, respectively, centrifuged at $10000 \times g$ for $30 \mathrm{~min}$, and the supernatants were collected for the extraction of viral RNA using the Virus Nucleic Acid Extraction Kit II (Geneaid, Taiwan). All tissues collected above, including blood, were used for virus titration; the lung, brain and heart were also used for histological and immunohistochemical analysis at $6 \mathrm{dpi}$.

\section{Real-time PCR for quantitation of viral loads}

Quantitative assays were carried out to measure viral loads in the blood and main organs [33]. Total RNA from tissues and blood samples was reverse transcribed using the PrimeScript ${ }^{\text {mi }}$ RT reagent Kit with gDNA Eraser (Perfect Real Time) (Takara, Dalian, China) and then run on an ABI 7500 Real Time PCR System using the SYBR1 Premix Ex TaqTM (Perfect Real Time) kit (Takara). Reverse transcription and cDNA amplification were carried out as described previously [8]. The primers used were designed against a region of the matrix gene: 5' - TCTATCGTCCCATCAGGC/GGTCTTGTCTTTAG CCATTC-3'. A reference standard was prepared using pMD19-T Simple Vector (50 ng/ $\mu \mathrm{L}$; Takara) that contained the corresponding target virus sequences. A series of eight 10 -fold dilutions equivalent to $1 \times 10^{3}-1 \times 10^{10}$ copies per reaction were prepared to generate calibration curves and were run in parallel with the test samples [35]. RNA of the amount of the two avian-origin CIV and human-origin influenza viruses was calculated from the standard curve by real-time RT-PCR. The detection limit of this assay was 1120 copies of RNA per $\mathrm{mL}$.

\section{Histopathology and immunohistochemical analysis}

After euthanasia at $6 \mathrm{dpi}$, the heart, brain and lung from the mice inoculated with $\mathrm{JS} / 10, \mathrm{GD} / 12, \mathrm{SD} / 05$ or PBS were collected and placed into 10\% neutral buffered formalin. After fixation the tissues were embedded in paraffin, sectioned at $4 \mu \mathrm{m}$ and stained with hematoxylin and eosin for histological evaluation. Sequential slides were stained using an immunoperoxidase method [8]. Expression of hemagglutinin in tissues was examined by immunohistochemical staining of histological sections. In brief, sections were blocked with $1 \%$ bovine serum albumin/PBS, stained with $\mathrm{mAb}$ D7 at a dilution of 1:5000 for one hour at $37{ }^{\circ} \mathrm{C}$, followed by biotin conjugated goat anti-mouse immunoglobulin (Bio-Rad) at a dilution of 1:200 for $30 \mathrm{~min}$ at $37^{\circ} \mathrm{C}$. The sections were subsequently incubated with HRP conjugated streptavidin (Bio-Rad) at $37^{\circ} \mathrm{C}$ for $30 \mathrm{~min}$. Sections were then developed with HRP-DAB chromogenic substrate kit (Tiangen) for 10 min and counterstained with hematoxylin. The lungs were assigned a grade of 0 to 3 based on the histological character of the lesions. Score criteria of different grades were in accordance with a previous study [36].

\section{Measurement of cytokines}

We further investigated if there was a correlation between severe disease and inflammatory cytokine production in virus-challenged mice, and ascertained whether passive immunization with antibodies affected the levels of cytokines involved in defense against three different influenza virus infections. Sections of the lungs (alternating right and left lungs) from all the mice were homogenized in $1 \mathrm{~mL}$ of PBS per $1 \mathrm{~g}$ of lung tissue. The homogenates were centrifuged, and the supernatants were frozen at $-70{ }^{\circ} \mathrm{C}$ until tested. The supernatants were assayed for gamma interferon (IFN- $\gamma$ ) and tumor necrosis factor (TNF- $\alpha$ ) using ELISA kits (Sigma-Aldrich, Beijing). The minimum detection limits of such assays were as follows: $25 \mathrm{pg} / \mathrm{mL}$ for TNF- $\alpha$ and $10 \mathrm{pg} / \mathrm{mL}$ for IFN- $\gamma$, as previously determined by the manufacturer.

\section{Statistical analysis}

Data were collected and analyzed using MS Excel 2010 and SPSS Statics v20.0 software. Weight loss, viral titers, cytokine levels and histological score were analyzed by analysis of variance (ANOVA), followed by Turkey's 
multiple comparison test with $P<0.05$ considered to be a significant difference, while $P<0.01$ was considered to be statistically extremely significant.

\section{Results}

Virus titers

CIV was propagated in MDCK cells and the titers of three viral strains, JS/10, GD/12 and $\mathrm{SD} / 05$ were determined to be $10^{7.13} \mathrm{TCID}_{50} / \mathrm{mL}, 10^{7.25} \mathrm{TCID}_{50} / \mathrm{mL}$ and $10^{8} \mathrm{TCID}_{50} / \mathrm{mL}$, respectively.

\section{Characterization of mAbs}

After fusion between spleen cells from H3N2 virusimmunized mice and sp2/0 myeloma cells, we obtained seven mAbs against the JS/10 virus. Isotyping tests showed that all of these mAbs were IgG2b isotypes, except for one that was IgG2a. Of the seven mAbs identified, four mAbs reacted with HA. Among these four mAbs, mAb D7 reacted with HA2 and three other mAbs reacted with HA1 (Figure 1), as demonstrated by western blotting. $\mathrm{HI}$ and neutralization titers of the seven mAbs showed that mAb D7 had the highest neutralization activity, but had no HI activity (Table 1). Further analysis indicated that $\mathrm{mAb}$ D7 could react with virus strains $\mathrm{JS} / 10, \mathrm{GD} / 12$ and $\mathrm{SD} / 05$, and produce high

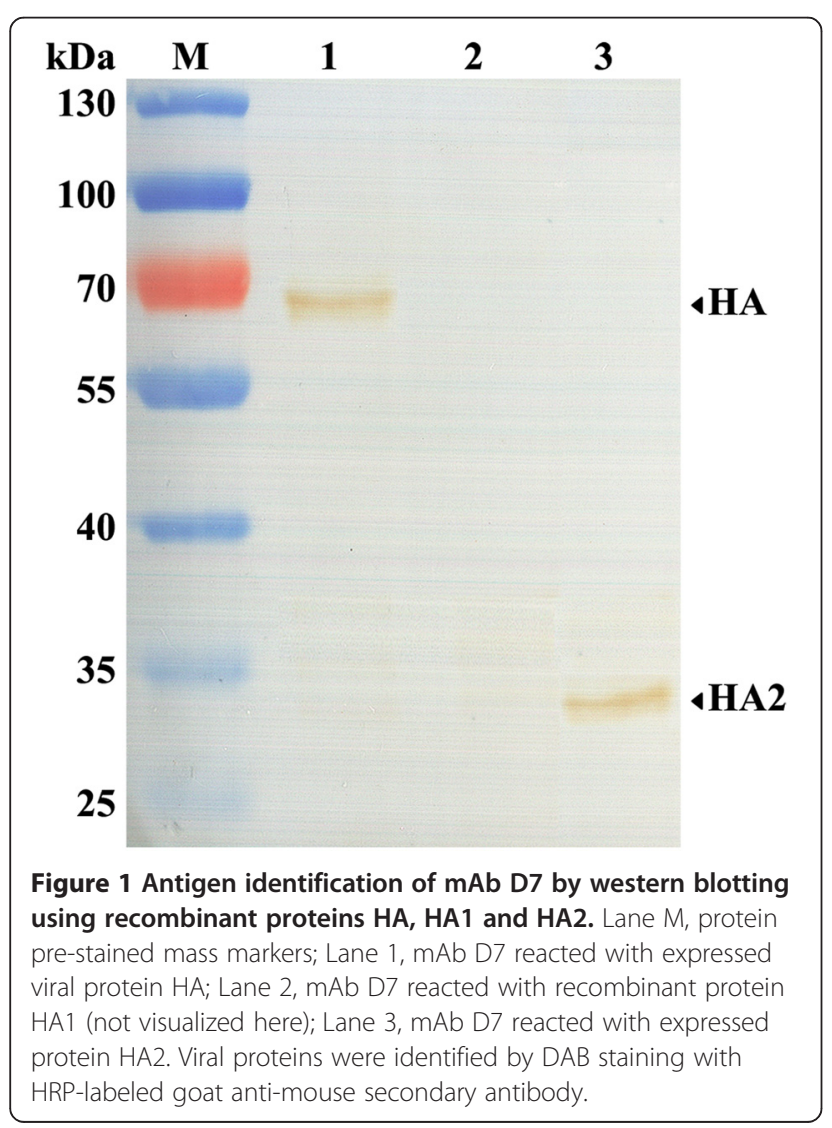

Table 1 Characteristics of seven monoclonal antibodies (mAbs) direct against JS/10

\begin{tabular}{llll}
\hline mAb & Isotype & Neutralization titer & HI titer \\
\hline B6 & $\lg G 2 a$ & 1600 & 320 \\
B7 & $\lg$ G2b & 1600 & 80 \\
B8 & $\operatorname{lgG} 2 b$ & 800 & 40 \\
D7 & $\lg$ G2b & 12800 & 0 \\
D8 & $\operatorname{lgG} 2 b$ & 6400 & 160 \\
G6 & $\operatorname{lgG} 2 b$ & 400 & 20 \\
H9 & $\lg G 2 b$ & 100 & 20 \\
\hline
\end{tabular}

neutralization activities against the three viral strains, especially against the homologous strain JS/10 (Table 2).

\section{MAb D7 in the treatment of influenza in mice}

To access the protective efficacy of $\mathrm{mAb} \mathrm{D} 7$, we inoculated mice with three different H3N2 strains one day after treatment with mAb D7. Three days after the inoculation, all mice challenged with the three virus strains exhibited clinical signs of infection, including depression, decreased activity and huddling. Similar clinical signs were observed in irrelevant $\mathrm{mAb} \operatorname{IgG}$ pretreated groups. However, similar to the PBS control group, mice in $\mathrm{mAb}$ D7 pretreated groups seemed to be energetic and had a good appetite during the infection.

In terms of body weight, mice challenged with JS/10 after treatment with D7 showed a similar increase in body weight compared with the PBS control group and there was no significant difference between the two groups (Figures 2A, B and C). At $14 \mathrm{dpi}$, mice treated with $\mathrm{mAb}$ D7 showed a body weight increase of nearly $30 \%$. Although the body weights in the virus-infected group and irrelevant mAb IgG group both demonstrated an upward trend, the growth rate was slower than that in the mAb D7 group. The extent of the increase in body weight was significantly slower compared with that of the mAb D7 group at 10, 12 and $14 \mathrm{dpi}(P<0.05)$ (Figure 2A). In the group of mice infected with $G D / 12$, the body weights of the mice in the three experimental groups all showed an upward trend, but the growth rate of the mice treated with mAb D7 was much higher than in the other two groups. In addition, the body weight changes of mice in the mAb D7 group at 10,12 and 14

Table 2 Characteristics of monoclonal antibody (mAb) D7 direct against virus strains JS/10, GD/12 and SD/05

\begin{tabular}{|c|c|c|c|c|}
\hline \multirow{2}{*}{$\begin{array}{l}\text { Virus } \\
\text { strains }\end{array}$} & \multicolumn{2}{|l|}{ mAb D7 } & \multicolumn{2}{|l|}{$\mathrm{mAb} \lg G$} \\
\hline & Neutralization titer & HI titer & Neutralization titer & $\mathrm{HI}$ titer \\
\hline$J S / 10$ & 12800 & 0 & 0 & 0 \\
\hline $\mathrm{GD} / 12$ & 6400 & 0 & 0 & 0 \\
\hline SD/05 & 3200 & 0 & 0 & 0 \\
\hline
\end{tabular}




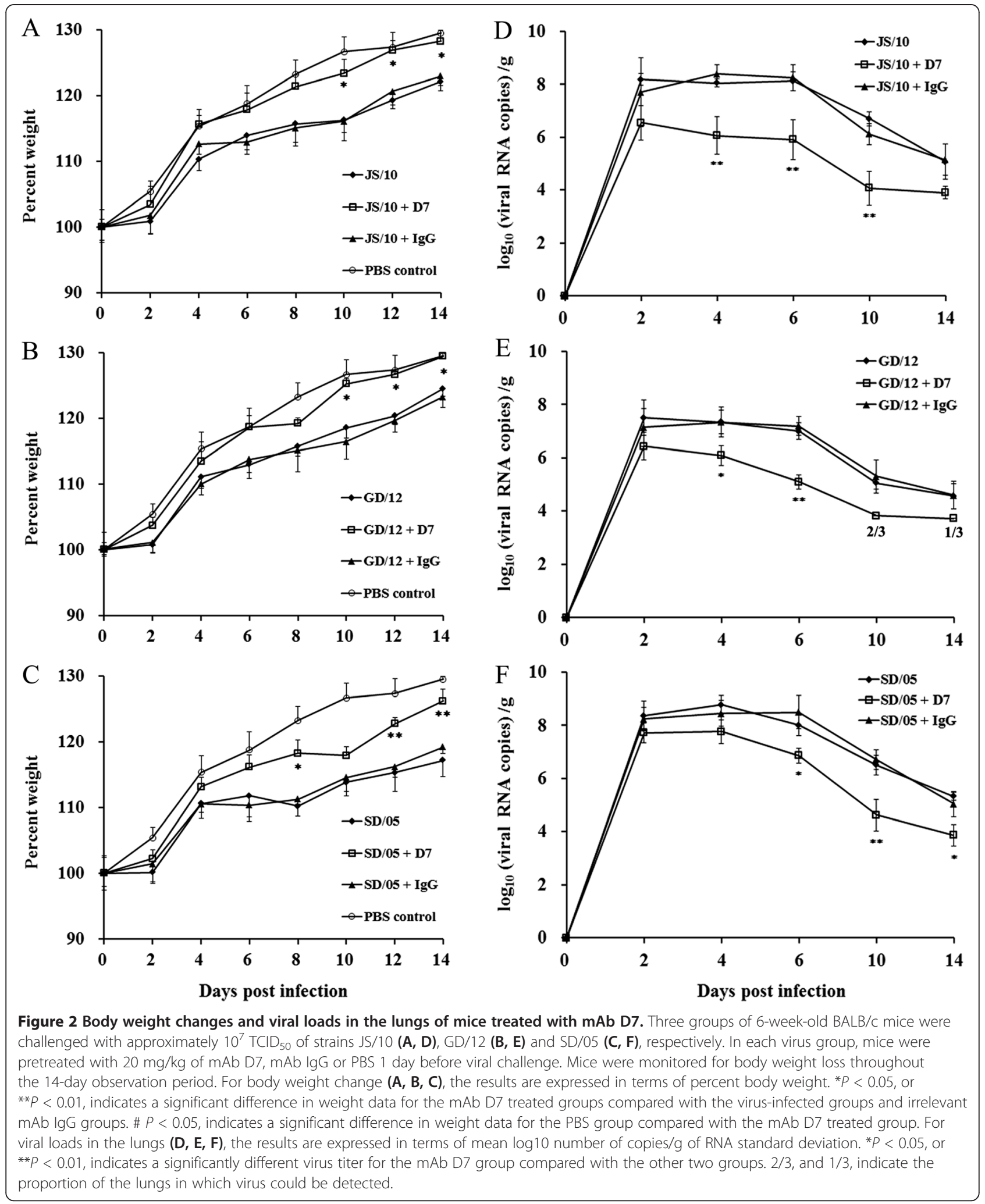

dpi were significantly different from those of the other two experimental groups $(P<0.05)$. The mice in the $\mathrm{mAb}$ D7 group showed weight gains of nearly $30 \%$, which was not significantly different from the PBS control group (Figure 2B). However, after infection with $\mathrm{SD} / 05$, mice in the virus-infected group showed a slight 
decrease in body weight at $6 \mathrm{dpi}$ and mice in the mAb IgG group displayed a slight decline at 8 dpi. By contrast, mice in the $\mathrm{mAb}$ D7 group continued to grow at $8(P<0.05), 12(P<0.01)$ and $14 \mathrm{dpi}(P<0.01)$. The growth rate in the $\mathrm{mAb} D 7$ group was significantly higher than that in the virus-infected group and $\mathrm{mAb}$ IgG group, but slightly lower than in the PBS control group at $14 \mathrm{dpi}$; mice body weight gain in the mAb group reached approximately 25\% (Figure 2C).

\section{Quantitation of viral RNA loads}

Real-time PCR was used to evaluate the kinetics of viral RNA loads in the lung, heart, brain, spleen, intestine, feces and blood of the infected mice. The viral titers were expressed as the number of copies of viral RNA. The dynamic changes of viral titers in the lungs of mice in the virus-infected group, mAb D7 group and irrelevant $\mathrm{mAb}$ IgG group were similar: peak viral titers were observed at 2, 4 and 6 days after infection, after which the viral titer declined at 10 and $14 \mathrm{dpi}$ (Figures 2D, E and F). However, viral titers in the lungs of mice treated with $\mathrm{mAb}$ D7 were significantly lower than in the mice in the other two groups at specific time points. After challenge with $\mathrm{JS} / 10$, viral loads in lungs of mice treated with $\mathrm{mAb}$ D7 were significantly lower than those in the other two groups at 4, 6 and $10 \mathrm{dpi}(P<0.01)$ (Figure 2D). For strain $\mathrm{GD} / 12$, viral titers of the lungs in the mAb D7 group were significantly lower compared with the other two experimental groups at $4(P<0.05)$ and 6 dpi $(P<0.01)$. In addition, at 10 and $14 \mathrm{dpi}$, viral RNA could not be detected in some lung samples ( $1 / 3$ and $2 / 3$, respectively) in the $\mathrm{mAb}$ D7 group (Figure 2E). For virus $\mathrm{SD} / 05$, the viral titer of mice in the mAb D7 group was significantly lower than in the other two groups at $6(P<0.05), 10(P<0.01)$ and $14 \mathrm{dpi}(P<0.05)$ (Figure $2 \mathrm{~F})$. For mice in the virus-infected group, peak viral titers of three virus strains JS/10, GD/12 and $\mathrm{SD} / 05$ were $10^{8.4}, 10^{7.3}$, $10^{8.5}$ copies/g, respectively, while for mice in the $\mathrm{mAb}$ D7 group, peak values were $10^{6.5}, 10^{6.4}$ and $10^{7.8}$ copies/g, respectively.

Considering that $\mathrm{mAb}$ D7 resulted in a significant reduction in viral titers in the lungs of mice infected with three different virus strains at $6 \mathrm{dpi}$, we chose that time point to determine the viral RNA loads in different tissues and fecal samples. We found that viral loads in collected feces, blood and other tissues at $6 \mathrm{dpi}$ in the $\mathrm{mAb}$ D7 group were also lower than those in the other two groups (Figure 3). After mice were challenged with virus $\mathrm{JS} / 10$, viral titers of the lung, heart, intestine, feces and blood in the mAb D7 group decreased by $192(P<0.01)$, $145(P<0.05), 20(P<0.05), 82(P<0.01)$ and 26 $(P<0.01)$ fold, respectively, compared to the other two groups (Figure 3A). For mice challenged with virus $\mathrm{GD} / 12$, viral titers of the lung, heart, spleen, feces and blood of mice treated with mAb D7 were found to be reduced by 103 ( $P<0.01), 30(P<0.01), 25(P<0.05), 13$ $(P<0.05)$ and $31(P<0.05)$ fold in comparison with the other two groups (Figure 3B). For virus SD/05, mAb D7 resulted in a reduction in viral titers of the lung, spleen, intestine, feces and blood by $13(P<0.05), 21(P<0.05)$, $57(P<0.05), 33(P<0.05)$ and $10(P<0.05)$ fold, respectively (Figure $3 C$ ).

Generally, mAb D7 could reduce viral loads of the three virus strains in the infected mice. Notably, in the virus-infected group and irrelevant $\mathrm{mAb} \operatorname{IgG}$ group, after infection with virus $J S / 10$, even till $14 \mathrm{dpi}$, virus RNA was detected in most tissues, while for the mice treated with mAb D7, virus RNA could not be detected in the brain and almost all the other tissues, except for the lung and blood, at $14 \mathrm{dpi}$ (Additional file 1). For virus $\mathrm{GD} / 12$, at $10 \mathrm{dpi}$, viral titers in all the detected tissues were much lower compared with the other two viruses, in all three groups. Viral titers in some tissues were undetectable. Mice in the mAb D7 group showed a much faster virus clearance rate than the other two groups. At $10 \mathrm{dpi}$, no virus was detected in the intestines and feces of three mice in the mAb D7 group and at 14 $\mathrm{dpi}$, virus was undetectable in all the other tissues in mice treated with mAb D7, except for the lungs in one mouse (Additional file 2). However, in mice infected with $\mathrm{SD} / 05$, the virus showed the longest retention time. At 14 dpi, nearly all tissues from mice in virus-infected and irrelevant $\mathrm{mAb}$ IgG groups showed detectable virus RNA. Even in the mAb D7 group, all mice showed positive virus RNA in the detected tissues, except for the intestines and feces (Additional file 3).

\section{Histopathological and immunohistochemical findings}

To compare the above results with pathological findings in mice infected with three different virus strains, and treated with mAb D7 and irrelevant $\mathrm{mAb}$ IgG, we chose the heart, brain and lung from different treatment groups at 6 dpi to perform histopathological and immunohistochemical analysis. All the sampled tissues from mice in the virus-infected group showed significant lesions and viral antigen staining, while those from the control group did not show any lesions. Mice treated with mAb D7 had markedly fewer lesions compared with the virus-infected group (Figure 4). Histological lesions in the mAb IgG group showed similar results with those in the virus-infected group (data not shown).

Regardless of virus strain, the lung interstitial space was obviously widened, and the bronchial lumen became narrow, with the alveolar septum thickened by the infiltration of a number of inflammatory cells (Figures 4A and C). Large areas of the lung appeared consolidated, with symptoms of pulmonary congestion (Figure 4E). Interstitial pneumonia was also obvious, with the alveolar 


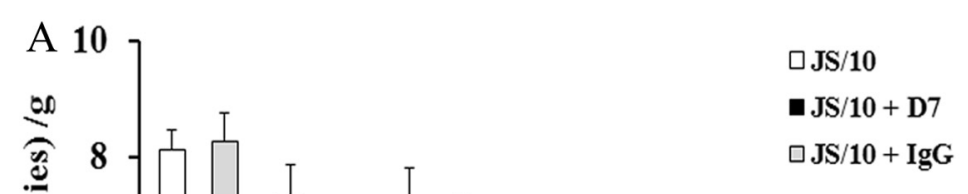


septum and proliferation of connective tissue infiltrated with numerous macrophages around the bronchioli and blood vessels (Figures $4 \mathrm{C}$ and E). In brief, histological lesions were characterized by multifocal to coalescing reddish consolidation in mice infected with the virus $J S / 10$, $\mathrm{GD} / 12$ or $\mathrm{SD} / 05$ in both the virus-infected and irrelevant $\mathrm{mAb}$ IgG groups. However, the degree of histological lesions observed for $\mathrm{SD} / 05$ was the most severe, and GD/12 showed the least severe lesions among these three viruses. Mice treated with $\mathrm{mAb}$ D7 showed only mild necrotizing bronchiolitis and ciliated tracheal epithelium with mild hyperplasia (Figure 4F). In addition, very small gaps were observed between the alveoli and there were no excessive amounts of alveolar macrophages in the lung (Figures 4B and $\mathrm{D}$ ). For virus strain GD/12, mAb D7 demonstrated the best protective efficacy compared with the other two viruses. Mice in the PBS group showed bronchia with a simple ciliated columnar epithelium and the alveolar cavity as a vacuolated thin-walled structure (Figure 4G). Viral antigen staining was present in almost all bronchiolar epithelial cells and some alveolar cells at $6 \mathrm{dpi}$ after virus challenge (Figures $5 \mathrm{~A}, \mathrm{C}$ and $\mathrm{E}$ ), while mice in $\mathrm{mAb}$ D7 showed only a little virus antigen staining surrounding vessels near the alveoli (Figures $5 \mathrm{~B}, \mathrm{D}$ and $\mathrm{F}$ ). The PBS control group had no viral staining (Figure 5G). Lung grades for degree of injury at 6 dpi are shown in Figure 6 . There was significantly less injury to the lungs in the $\mathrm{mAb}$ D7 group than in the virus-infected group and $\mathrm{mAb} \operatorname{IgG}$ group for all virus strains.

Similar to the lung, all mice in the virus-infected groups showed histological lesions in the brain. The extent of histological lesions infected was the most severe with $\mathrm{SD} / 05$ and was the least severe for GD/12. The severity of the infection may depend on the differences in virus titer. In the cerebrum, congestion and hemorrhage were evident. Nerve fibers were dissolved and neurons had necrolysis-like vacuoles; glial nodules and neuronophagia were also observed (Figures $4 \mathrm{O}$ and Q). Dilation and hyperemia were found in the capillaries (Figure 4S). Moreover, microglial cells and nerve cells showed a satellite phenomenon. The cytoplasm of the neurons was basophilic because of contraction (Figures $4 \mathrm{O}$ and Q). Viral antigens could be detected in glial nodules and microglial-gathered areas (Figures 5O, $\mathrm{Q}$, and S). The brains of mice treated with $\mathrm{mAb}$ D7 had only mild lesions surrounding microglial cells and nerve cells (Figures $4 \mathrm{P}$ and $\mathrm{T}$ ), and almost no antigen staining was found (Figures 5R and T). The PBS control group showed no histological findings (Figure $4 \mathrm{U}$ ) and no viral staining (Figure 5U).

In the heart, for all mice in virus-infected groups, the cardiac striated muscle was disordered and full of vacuoles, characterized by myocarditis, and lymphocyte infiltration was observed (Figure 4H). Lymphoproliferation was also found among the muscle fibers (Figure 4J). The nuclei showed pyknosis, with some myocardial cells showing coagulative necrosis (Figures $4 \mathrm{~J}$ and $\mathrm{L}$ ), which was consistent with heavy antigen staining (Figures $5 \mathrm{H}$, J and L). No significant differences in microscopic lesions (Figures 4I, K, $\mathrm{M}$ and $\mathrm{N}$ ) and viral antigen staining (Figures 5I, K, M and N) were found between the mAb D7 and PBS groups.

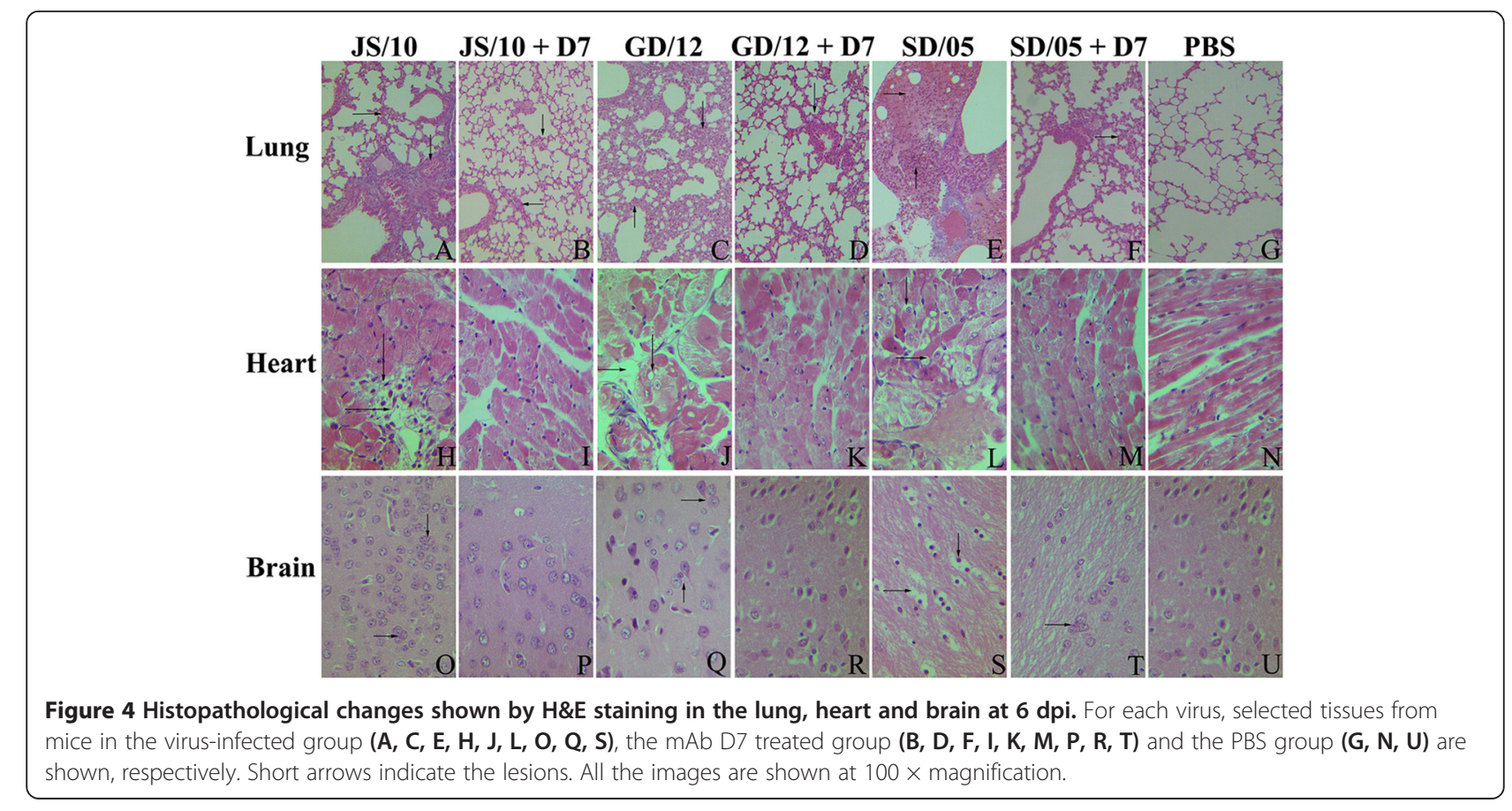




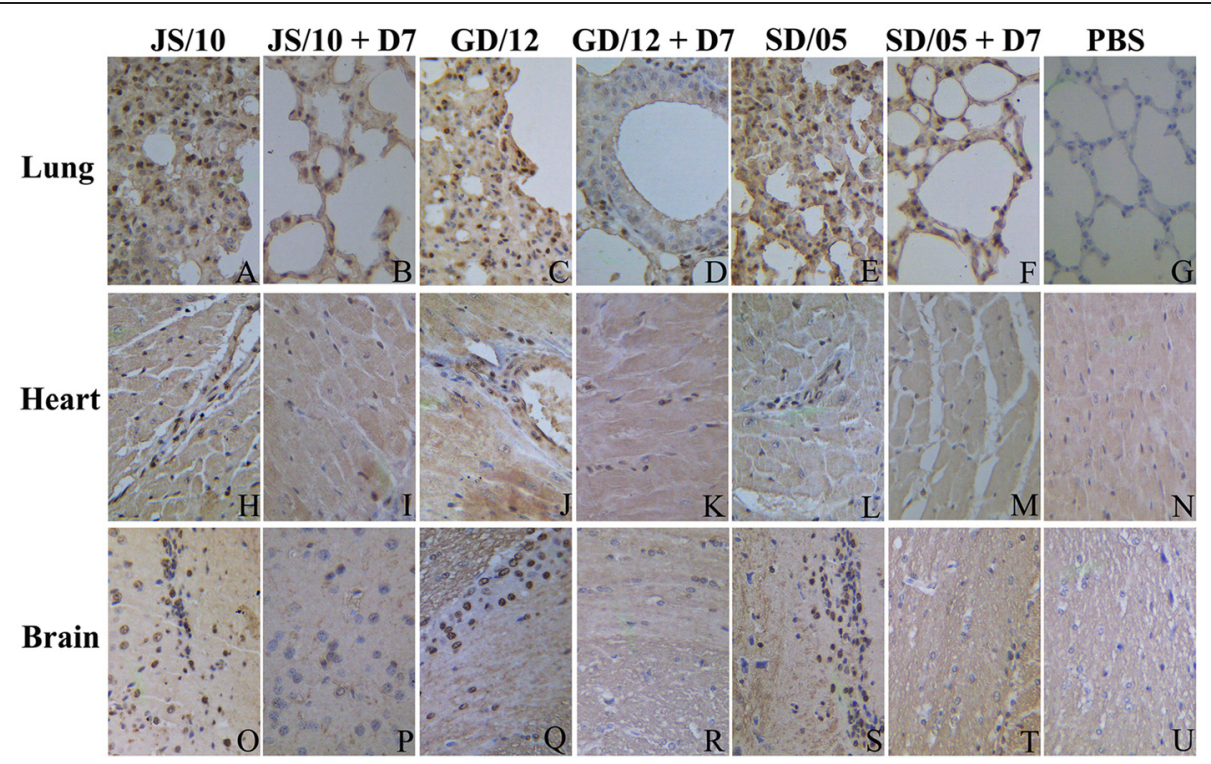

Figure 5 Immunohistochemical detection of influenza viral antigen in the lung, heart and brain at 6 dpi. For each virus, selected tissues from mice in the virus-infected group $(\mathbf{A}, \mathbf{C}, \mathbf{E}, \mathbf{H}, \mathbf{J}, \mathbf{L}, \mathbf{O}, \mathbf{Q}, \mathbf{S})$, the mAb D7 treated group (B, D, F, I, K, M, $\mathbf{P}, \mathbf{R}, \mathbf{T})$ and the PBS group (G, N, U) are shown, respectively. All the images are shown at $400 \times$ magnification.

\section{Cytokine response in lung tissue}

To gain a better understanding of the effect of CIV on the innate immune response and to ascertain whether passive immunization with monoclonal antibody affected the levels of cytokines, we examined the levels of IFN- $\gamma$ and TNF- $\alpha$ in the lungs of mice in the virus-infected and $\mathrm{mAb}$ D7 groups.

As shown in Figure 7, the level of IFN- $\gamma$ in response to all three virus strains showed an identical trend, higher at

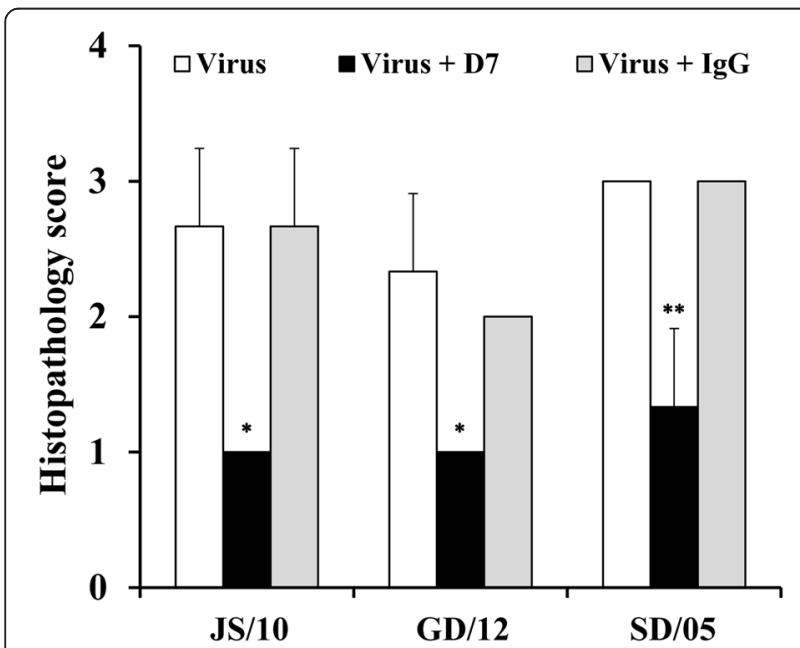

Figure 6 The degree of lung injury after infection with virus JS/10, GD/12 and SD/05 at 6 dpi. The lungs were assigned a grade 0 to 3 based on the histological character of the lesions. ${ }^{*} P<0.05$, or ${ }^{*} P<0.01$, indicates a significantly different score for the mAb D7 group compared with the other two groups.
2, 4 and 6 dpi than at 10 and $14 \mathrm{dpi}$. The IFN- $\gamma$ levels in $\mathrm{mAb}$ D7 group in all three virus strains were significantly lower than the virus-infected group or mAb IgG group, especially at 6,10 and $14 \mathrm{dpi}$. However, the cytokine levels differed with the various virus strains.

For virus strain JS/10, the IFN- $\gamma$ level of all groups reached its peak at $2 \mathrm{dpi}$, and then exhibited an overall downward trend. The cytokine levels in the mAb D7 group at $6(P<0.01)$ and $10 \mathrm{dpi}(P<0.05)$ were significantly lower than that in the virus-infected or mAb IgG group; however, the IFN- $\gamma$ level did not show any significant difference among the three groups at other time points (Figure 7A). The IFN- $\gamma$ level in the $\mathrm{mAb}$ D7 group returned to normal after $10 \mathrm{dpi}$, while the other two groups returned to the normal level at $14 \mathrm{dpi}$.

For virus strain GD/12, the IFN- $\gamma$ levels of the three experimental groups were significantly higher than in the mice in the PBS group at $2(P<0.01), 4(P<0.01)$ and $6 \mathrm{dpi}(P<0.01)$, sustaining a relatively high level until $10 \mathrm{dpi}$, after which it decreased. The peak level of IFN- $\gamma$ in the mAb IgG group was lower compared with the other two virus strains at 2 dpi (Figure 7B). Although the IFN- $\gamma$ levels in the three experimental groups challenged with GD/12 did not show much difference compared with each other, the IFN- $\gamma$ level in the mAb D7 group at $10 \mathrm{dpi}$ returned to a normal level, which was significantly lower $(P<0.05)$ compared with the other two groups; all the three groups showed normal levels at 14 dpi.

For virus strain $\mathrm{SD} / 05$, this virus induced the largest rise in IFN- $\gamma$ levels. The level in the SD/05-infected 


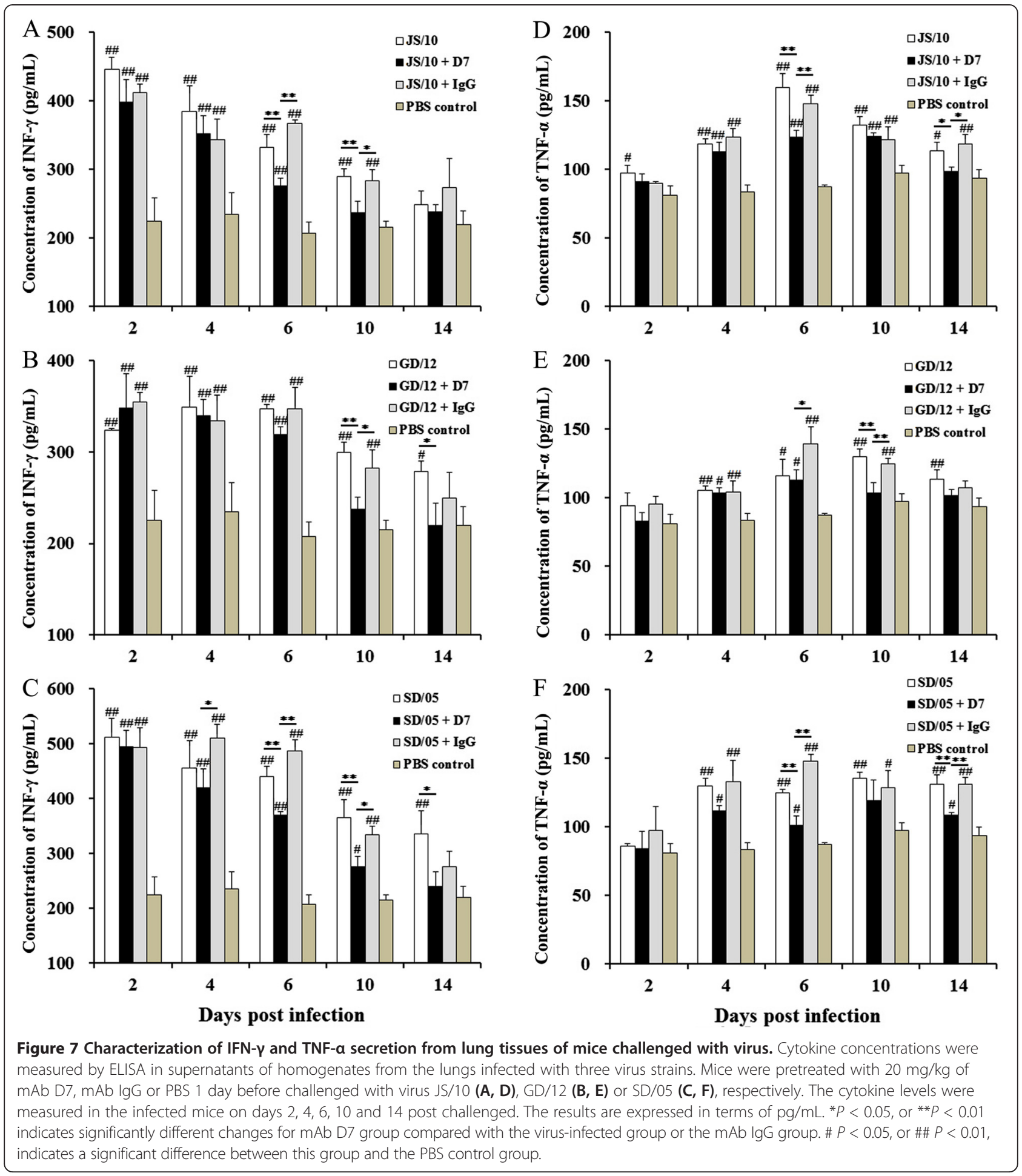

group was significantly higher than that of the other two viruses at $2 \mathrm{dpi}$. In addition, mice in virus-infected and $\mathrm{mAb}$ IgG groups both demonstrated the same trend in the period of 2 to $10 \mathrm{dpi}(P<0.01)$, i.e., significant elevation followed by a downward trend (Figure $7 \mathrm{C}$ ).
Although the IFN- $\gamma$ level in the mAb D7 group at 2 to 10 dpi was relatively high compared with the PBS group, the IFN- $\gamma$ levels were significantly lower than those of the other two groups at $6(P<0.01)$ and $10 \mathrm{dpi}$ $(P<0.05)$, and then declined to the normal level at $14 \mathrm{dpi}$. 
Changes in TNF- $\alpha$ level were not the same as those for IFN- $\gamma$. After infection with the three virus strains, TNF- $\alpha$ levels of mice in all groups were only slightly higher than those of the PBS group at $2 \mathrm{dpi}$ and increased at 4 and 6 dpi. Levels reached their maximum at $10 \mathrm{dpi}$ and decreased at $14 \mathrm{dpi}$, however, the cytokine level was still higher than that of the control group at 14 dpi which was quite different compared with the IFN- $\gamma$ level. The increase in TNF- $\alpha$ level was lower compared with the IFN- $\gamma$ level. In addition, the TNF- $\alpha$ level in the $\mathrm{mAb}$ D7 group was apparently lower than the virusinfected group or mAb IgG group, especially at 10 and 14. dpi.

For virus strain JS/10, TNF- $\alpha$ levels in the virusinfected group and mAb IgG group showed a small rise at $2 \mathrm{dpi}$, reaching its peak at $6 \mathrm{dpi}$, and then declined; however, the cytokine level was still significantly higher $(P<0.05)$ than that of the PBS group (Figure 7D). The TNF- $\alpha$ level in the mAb D7 group at $14 \mathrm{dpi}(P<0.05)$ was remarkably lower than that in the virus-infected group and $\mathrm{mAb}$ IgG group, and decreased to a similar level as the PBS group.

For virus strain GD/12, the TNF- $\alpha$ level of all three experimental groups increased from 2 to $6 \mathrm{dpi}$, and then returned to normal at $14 \mathrm{dpi}$ (Figure 7E). The TNF- $\alpha$ level of the mAb D7 group at 10 dpi was significantly lower $(P<0.05)$ than in the other two groups, while the cytokine level did not show much difference in these three groups at the other time points.

For virus strain $\mathrm{SD} / 05$, the TNF- $\alpha$ levels in the virusinfected group and $\mathrm{mAb}$ D7 group were markedly higher than those of the PBS group from 4 to $14 \mathrm{dpi}$ (Figure 7F). Although the TNF- $\alpha$ level in the mAb D7 group was also significantly higher $(P<0.05)$ than the PBS group, except at 2 and $10 \mathrm{dpi}$, the level in the mAb D7 group was significantly lower $(P<0.01)$ compared with the virus-infected and irrelevant mAb IgG groups at 6 and 14 dpi.

\section{Discussion}

H3N2 CIV is a newly identified avian influenza virus (AIV) subtype that can infect dogs and transmit directly from dog to dog $[5,8]$. CIV infection has been reported in several countries, including South Korea and China $[9,10,37]$. It is important to develop a set of measures to prevent and control CIV infection in dogs.

Antibody-mediated passive immunity can provide protection against invading pathogens [38,39]. In this study, we developed seven mAbs against JS/10, whose pathogenicity has been characterized both in mice [8] and dogs [40]. Among them, four mAbs reacted with HA. The HA glycoprotein is the primary target of antibodies that confer protective immunity to influenza viruses [41]. Therefore, the generation of neutralizing antibodies against antigenic sites on the HA glycoprotein is regarded as a criterion for evaluating immunity to influenza viruses and is believed to constitute the main correlate of protection [42,43]. Anti-HA globular head mAbs have potent neutralizing activity against homologous strains, but have very limited breadth of reactivity because of the high variability of amino-acid changes in the HA1 globular head [44]. HA2, which is the HA stalk, however, is a conserved region of HA among all influenza A virus subtypes $[33,45]$ and is responsible for the fusion of the virus and the endosomal membrane during the entry of the virus into the cell [20]. Here, western blotting showed that MAb D7 recognized the HA2 domain of $\mathrm{H} 3$, and had highest neutralization activities. Although MAb D7 lacked HI activity, some previous studies reported that a lack of in vitro $\mathrm{HI}$ activity of anti-HA2 MAbs does not rule out protective activity in vivo $[33,45]$. Therefore, we selected the anti-HA2 MAb D7 for further evaluation in regards to protection against different influenza virus strains.

To investigate the protection of $\mathrm{mAb}$ D7 against homologous and heterologous strains of H3N2 influenza viruses, we selected three virus strains to perform the challenge experiment in mice, including two strains of CIV (JS/10 and GD/12) and one strain of swine influenza virus (SIV) (SD/05). Considering that almost all H3N2 CIV isolates reported were not lethal to mice or dogs in challenge experiment $[5,8,10,15,40]$, we evaluated the protection efficacy by body weights, viral loads and histological lesions. Body weight loss is the parameter most commonly used to evaluate influenza viral pathogenicity in mice [46]. Our study shows that all three virus strains could remarkably reduce the growth rate of the mice after infection, while pretreatment with $\mathrm{mAb}$ D7 helped to control the declination to some extent. From the pathological point of view, the lung, heart and brain in mAb D7 treated groups showed markedly fewer lesions compared with the virus-infected group and $\mathrm{mAb}$ IgG group, with all virus strains. The pathological scores of the lungs in $\mathrm{mAb}$ D7 group were lower than those in the virus-infected group and $\mathrm{mAb}$ IgG group, suggesting that $\mathrm{mAb} D 7$ could mitigate the damage caused by influenza virus. These results suggest that mAb D7 could offer a protective effect against the three virus strains.

To further evaluate the effects of the anti-influenza virus $\mathrm{mAb}$, we monitored viral loads by real-time PCR. The mAb D7 decreased the viral loads in the lungs to significantly lower levels, relative to those in the virusinfected group and mAb IgG group. Similar results were also found in other tissues. For JS/10, the virus in the brain and other organs of all three mice treated with $\mathrm{mAb}$ D7 had been cleared by $10 \mathrm{dpi}$, except for the lungs. For virus GD/12, the application of $\mathrm{mAb} \mathrm{D} 7$ 
caused virus clearance from the intestine and feces 4 days earlier than that in the other two groups; moreover, there was no detectable virus RNA at 14 dpi. For virus $\mathrm{SD} / 05$, a slower rate of clearance of viral load was observed. This virus could persist and be detected in most tissues in the mAb D7 group until $14 \mathrm{dpi}$, but virus in the intestine and feces had been cleared by $14 \mathrm{dpi}$. These results indicate that protection against the virus strains provided by mAb D7 might be caused by earlier clearance of the virus from the tissues or shortening the time of virus shedding. A previous study has reported that mAbs could reduce the period of virus clearance [23].

Our study indicates that mAb D7 could provide good protection against challenge with homologous, as well as heterologous, virus strains of H3N2 influenza virus. This finding was in accordance with a previous report [47] that HA2 mAbs are highly cross-reactive among strains of the same subtype, and even within different subtypes. In spite of this, we found that this mAb was relatively less effective against the swine-lineage than caninelineage $\mathrm{H} 3$ virus strains. Sequence analysis of amino acids showed that JS/10 had higher sequence identity to canine-lineage GD/12 (98.6\%) than to swine-lineage SD/05 (84.8\%), with 3 and 16 different amino acids, respectively, in HA2 (data not shown). The difference in amino acid sequence may affect antigen-antibody recognition. This may explain why the mAb induced by canine-lineage influenza virus strain JS/10 is not strong enough to react against more distantly related strains within the same subtype.

Cytokines are important in establishing an innate immune response, as well as in determining the magnitude of the inflammatory response to influenza virus infection. The most important feature of the mechanism of immune suppression with influenza virus H5N1 is the cytokine storm $[11,48]$. Here, to gain a better understanding of how virus infection and $\mathrm{mAb}$ treatment affected host immune response, we analyzed the levels of IFN- $\gamma$ and TNF- $\alpha$ in the lung.

An important finding in this study is that the TNF- $\alpha$ levels peaked two days later than IFN- $\gamma$ levels in all groups. A previous study showed similar results: IFN $-\gamma$ and TNF- $\alpha$ in the lungs of pigs infected with human H1N1 influenza virus peaked at $3 \mathrm{dpi}$, and $6 \mathrm{dpi}$ respectively [49]. IFN- $\gamma$ has important immune-regulatory functions and antiviral activity, and is primarily produced by natural killer (NK) and T cells. NK cells are a major player in innate immune responses. We speculated that early production of IFN- $\gamma$ during infection probably arises from NK cells, whereas TNF- $\alpha$ functions relatively late in the inflammatory cycle induced by infection, at a time when virus is already being contained and the response is centered on resolution of the inflammation $[50,51]$. TNF- $\alpha$ in mice challenged by JS/10 and
SD/05 maintained higher levels until 14 dpi. A previous study demonstrated that the depletion of TNF- $\alpha$ in influenza or respiratory syncytial virus-infected animals significantly reduced pulmonary inflammation and cytokine production, without compromising viral clearance [52]. We speculated that the elevated level of TNF- $\alpha$ at 14 dpi might be correlated with the uncleared virus loads in the lungs.

In the present study, three strains of H3N2 CIV were shown to induce elevated levels of cytokines in the lungs. This was in agreement with previous reports on H3N2 CIV $[37,53]$. During H5N1 influenza virus infection, the elevated pro-inflammatory cytokine response has been proposed as the main cause of the increased severity of the disease [54]. The study of Lee et al. [55] reported that the levels of IFN- $\gamma$ and TNF- $\alpha$ in the lungs of dogs infected with H3N2 influenza virus increased quickly, while the infected dogs developed severe bronchointerstitial pneumonia accompanied with massive infiltration of immune cells. This result suggests that the dysregulation of chemokines during H3N2 CIV infection might contribute to viral pneumonia characterized by extensive immune cell infiltration. In support of this hypothesis, we observed that elevated levels of cytokines accompanied the clinical manifestations in the CIV infected dogs.

We found that IFN- $\gamma$ and TNF- $\alpha$ levels in the mAb D7 group were significantly lower than in the virus-infected group or mAb IgG group, while the histopathological findings showed more significant lesions in lungs of mice from the latter two groups than in the mAb D7 group. These observations indicate that mAb D7 treatment may reduce the virus-induced cytokine production and pathological lesions caused by virus infection. The effect is likely to be mediated by inhibition of CIV replication by the mAb. Fritz et al. [50] reported that active influenza virus replication is required for the induction of potent proinflammatory, regulatory and chemotactic factors.

Our study and a previous report [55] demonstrate that active replication of CIV in the canine respiratory system results in intense inflammatory responses. Considering that it is important for the host to maintain a balance of the cytokine levels, we speculated that inhibition of the inflammatory cytokine response might offer a therapy for CIV infection. However, Salomon et al. [56] demonstrated that inhibition of the cytokine response during H5N1 influenza virus infection is not sufficient to protect against death, and proposed that therapies targeting the virus would be preferable.

In conclusion, our results suggest that the HA2-specific mAb D7 could contribute to early recovery from influenza infection with different $\mathrm{H} 3 \mathrm{~N} 2$ virus strains. This mAb will further our understanding of the antigenic properties of H3N2 virus and might contribute to the prevention and control of $\mathrm{H} 3 \mathrm{~N} 2$ virus epidemic in dogs. 


\section{Additional files}

Additional file 1: Viral RNA detection in collected samples of mice inoculated with virus strain JS/10. Numbers 1,2 and 3 represent the three mice euthanized from each group at different dpi. + represents viral loads in terms of mean log10 number of copies/g of RNA. Numbers of + 's represent the magnitude of RNA copies.

Additional file 2: Viral RNA detection in collected samples of mice inoculated with virus strain GD/12. Numbers 1, 2 and 3 represent the three mice euthanized from each group at different dpi. + represents viral loads in terms of mean log10 number of copies/g of RNA. Numbers of + 's represent the magnitude of RNA copies.

Additional file 3: Viral RNA detection in collected samples of mice inoculated with virus strain SD/05. Numbers 1,2 and 3 represent the three mice euthanized from each group at different dpi. + represents viral loads in terms of mean log10 number of copies/g of RNA. Numbers of + 's represent the magnitude of RNA copies.

\section{Competing interests}

The authors declare that they have no competing interests.

\section{Authors' contributions}

$X X$ carried out most of the experiments described in the manuscript and wrote the article; YL, MDP participated in the design of the study and performed the statistical analysis; YBZ, DHK, CPL helped with the animal experiments. YJL conceived the study and contributed in its design and coordination. All authors read and approved the final manuscript.

\section{Acknowledgements}

This work was supported by the International S\&T Cooperation Program of China (ISTCP 2014DFG32770) and the Priority Academic Program

Development of Jiangsu Higher Education Institutions (PAPD).

Received: 21 August 2014 Accepted: 8 January 2015

Published online: 19 March 2015

\section{References}

1. Ali A, Daniels JB, Zhang Y, Rodriguez-Palacios A, Hayes-Ozello K, Mathes $L$ (2011) Pandemic and seasonal human influenza virus infections in domestic cats: prevalence, association with respiratory disease, and seasonality patterns. J Clin Microbiol 49:4101-4105

2. Neumann G, Kawaoka $Y$ (2006) Host range restriction and pathogenicity in the context of influenza pandemic. Emerg Infect Dis 12:881-886

3. Crawford PC, Dubovi EJ, Castleman WL, Stephenson I, Gibbs EP, Chen L, Smith C, Hill RC, Ferro P, Pompey J, Bright RA, Medina MJ, Johnson CM, Olsen CW, Cox NJ, Klimov Al, Katz JM, Donis RO (2005) Transmission of equine influenza virus to dogs. Science 310:482-485

4. Payungporn S, Crawford PC, Kouo TS, Chen LM, Pompey J, Castleman WL, Dubovi EJ, Katz JM, Donis RO (2008) Influenza A virus (H3N8) in dogs with respiratory disease, Florida. Emerg Infect Dis 14:902-908

5. Song D, Kang B, Lee C, Jung K, Ha G, Kang D, Park S, Park B, Oh J (2008) Transmission of avian influenza virus (H3N2) to dogs. Emerg Infect Dis 14:741-746

6. Song D, Lee C, Kang B, Jung K, Oh T, Kim H, Park B, Oh J (2009) Experimental infection of dogs with avian-origin canine influenza $A$ virus (H3N2). Emerg Infect Dis 15:56-58

7. Li S, Shi Z, Jiao P, Zhang G, Zhong Z, Tian W, Long LP, Cai Z, Zhu X, Liao M, Wan XF (2010) Avian-origin H3N2 canine influenza A viruses in Southern China. Infect Genet Evol 10:1286-1288

8. Lin Y, Zhao Y, Zeng X, Lu C, Liu Y (2012) Genetic and pathobiologic characterization of H3N2 canine influenza viruses isolated in the Jiangsu Province of China in 2009-2010. Vet Microbiol 158:247-258

9. Sun Y, Sun S, Ma J, Tan Y, Du L, Shen Y, Mu Q, Pu J, Lin D, Liu J (2013) Identification and characterization of avian-origin H3N2 canine influenza viruses in northern China during 2009-2010. Virology 435:301-307

10. Teng Q, Zhang X, Xu D, Zhou J, Dai X, Chen Z, Li Z (2013) Characterization of an H3N2 canine influenza virus isolated from Tibetan mastiffs in China. Vet Microbiol 162:345-352
11. Rockman S, Brown LE, Barr IG, Gilbertson B, Lowther S, Kachurin A, Kachurina O, Klippel J, Bodle J, Pearse M, Middleton D (2013) Neuraminidase-inhibiting antibody is a correlate of cross-protection against lethal H5N1 influenza virus in ferrets immunized with seasonal influenza vaccine. J Virol 87:3053-3061

12. Cada DJ (2013) Influenza vaccine progress. Hosp Pharm 48:266

13. Yamazaki $T$, Ichinohe $T$ (2014) Inflammasomes in antiviral immunity: clues for influenza vaccine development. Clin Exp Vaccine Res 3:5-11

14. Deshpande MS, Jirjis FF, Tubbs AL, Jayappa H, Sweeney D, Spencer SJ, Lakshmanan N, Wasmoen TL (2009) Evaluation of the efficacy of a canine influenza virus (H3N8) vaccine in dogs following experimental challenge. Vet Ther 10:103-112

15. Cho YS, Ha GW, Oh JS, Kang DS, Song D, Kang B, Lee CS. Canine influenza virus and vaccine therefore. United States Patent 2012. Patent NO: US 8,246,962 B2.

16. Friesen $\mathrm{RH}$, Koudstaal W, Koldijk MH, Weverling GJ, Brakenhoff JP, Lenting PJ, Stittelaar KJ, Osterhaus AD, Kompier R, Goudsmit J (2010) New class of monoclonal antibodies against severe influenza: prophylactic and therapeutic efficacy in ferrets. PLoS One 5:e9106

17. Smith NM, Bresee JS, Shay DK, Uyeki TM, Cox NJ, Strikas RA (2006) Prevention and control of influenza: recommendations of the advisory committee on immunization practices (ACIP). MMWR Recomm Rep 55:1-42

18. Greenough TC, Babcock GJ, Roberts A, Hernandez HJ, Thomas WD, Jr, Coccia JA, Graziano RF, Srinivasan M, Lowy I, Finberg RW, Subbarao K, Vogel L, Somasundaran M, Luzuriaga K, Sullivan JL, Ambrosino DM (2005) Development and characterization of a severe acute respiratory syndromeassociated coronavirus-neutralizing human monoclonal antibody that provides effective immunoprophylaxis in mice. J Infect Dis 191:507-514

19. Keller MA, Stiehm ER (2000) Passive immunity in prevention and treatment of infectious diseases. Clin Microbiol Rev 13:602-614

20. Skehel JJ, Wiley DC (2000) Receptor binding and membrane fusion in virus entry: the influenza hemagglutinin. Annu Rev Biochem 69:531-569

21. Rahim MN, Selman M, Sauder PJ, Forbes NE, Stecho W, Xu W, Lebar M Brown EG, Coombs KM (2013) Generation and characterization of a new panel of broadly reactive anti-NS1 mAbs for detection of influenza A virus. J Gen Virol 94:593-605

22. Gocnik M, Fislova T, Sladkova T, Mucha V, Kostolansky F, Vareckova E (2007) Antibodies specific to the HA2 glycopolypeptide of influenza A virus haemagglutinin with fusion-inhibition activity contribute to the protection of mice against lethal infection. J Gen Virol 88:951-955

23. Tumpey TM, Renshaw M, Clements JD, Katz JM (2001) Mucosal delivery of inactivated influenza vaccine induces B-cell-dependent heterosubtypic cross-protection against lethal influenza A H5N1 virus infection. J Virol 75:5141-5150

24. Chen Y, Qin K, Wu WL, Li G, Zhang J, Du H, Ng MH, Shih JW, Peiris JS, Guan Y, Chen H, Xia N (2009) Broad cross-protection against H5N1 avian influenza virus infection by means of monoclonal antibodies that map to conserved viral epitopes. J Infect Dis 199:49-58

25. Du L, Jin L, Zhao G, Sun S, Li J, Yu H, Li Y, Zheng BJ, Liddington RC, Zhou Y, Jiang S (2013) Identification and structural characterization of a broadly neutralizing antibody targeting a novel conserved epitope on the influenza virus H5N1 hemagglutinin. J Virol 87:2215-2225

26. Reed $\sqcup$, Muench $H$ (1938) A simple method for estimating fifty percent endpoints. Am J Hyg 27:493-497

27. Vareckova E, Betakova T, Mucha V, Solarikova L, Kostolansky F, Waris M, Russ $G$ (1995) Preparation of monoclonal antibodies for the diagnosis of influenza A infection using different immunization protocols. J Immunol Methods 180:107-116

28. Peterson EM, Cheng X, Pal S, de la Maza LM (1993) Effects of antibody isotype and host cell type on in vitro neutralization of Chlamydia trachomatis. Infect Immun 61:498-503

29. Wu WL, Chen Y, Wang P, Song W, Lau SY, Rayner JM, Smith GJ, Webster RG, Peiris JS, Lin T, Xia N, Guan Y, Chen H (2008) Antigenic profile of avian H5N1 viruses in Asia from 2002 to 2007. J Virol 82:1798-1807

30. Lee C, Jung K, Oh J, Oh T, Han S, Hwang J, Yeom M, Son D, Kim J, Park B, Moon H, Song D, Kang B (2010) Protective efficacy and immunogenicity of an inactivated avian-origin H3N2 canine influenza vaccine in dogs challenged with the virulent virus. Vet Microbiol 143:184-188

31. Kaverin NV, Rudneva IA, llyushina NA, Varich NL, Lipatov AS, Smirnov YA, Govorkova EA, Gitelman AK, Lvov DK, Webster RG (2002) Structure of antigenic sites on the haemagglutinin molecule of $\mathrm{H} 5$ avian influenza virus and phenotypic variation of escape mutants. J Gen Virol 83:2497-2505 
32. Narasaraju T, Sim MK, Ng HH, Phoon MC, Shanker N, Lal SK, Chow VT (2009) Adaptation of human influenza H3N2 virus in a mouse pneumonitis model: insights into viral virulence, tissue tropism and host pathogenesis. Microbes Infect 11:2-11

33. Prabhu N, Prabakaran M, Ho HT, Velumani S, Qiang J, Goutama M, Kwang J (2009) Monoclonal antibodies against the fusion peptide of hemagglutinin protect mice from lethal influenza A virus H5N1 infection. J Virol 83:2553-2562

34. Wallach MG, Webby RJ, Islam F, Walkden-Brown S, Emmoth E, Feinstein R, Gronvik KO (2011) Cross-protection of chicken immunoglobulin $Y$ antibodies against $\mathrm{H} 5 \mathrm{~N} 1$ and $\mathrm{H} 1 \mathrm{~N} 1$ viruses passively administered in mice. Clin Vaccine Immunol 18:1083-1090

35. To KK, Chan KH, Li IW, Tsang TY, Tse H, Chan JF, Hung IF, Lai ST, Leung CW, Kwan YW, Lau YL, Ng TK, Cheng VC, Peiris JS, Yuen KY (2010) Viral load in patients infected with pandemic H1N1 2009 influenza A virus. J Med Virol 82:1-7

36. Alymova IV, Green AM, van de Velde N, McAuley JL, Boyd KL, Ghoneim HE, McCullers JA (2011) Immunopathogenic and antibacterial effects of H3N2 influenza A virus PB1-F2 map to amino acid residues 62, 75, 79, and 82. J Virol 85:12324-12333

37. Jeoung HY, Lim SI, Shin BH, Lim JA, Song JY, Song DS, Kang BK, Moon HJ, An DJ (2013) A novel canine influenza H3N2 virus isolated from cats in an animal shelter. Vet Microbiol 165:281-286

38. Casadevall A, Pirofski LA (2004) New concepts in antibody-mediated immunity. Infect Immun 72:6191-6196

39. Parren PW, Geisbert TW, Maruyama T, Jahrling PB, Burton DR (2002) Preand postexposure prophylaxis of Ebola virus infection in an animal model by passive transfer of a neutralizing human antibody. J Virol 76:6408-6412

40. Zeng XJ, Lin Y, Zhao YB, Lu CP, Liu YJ (2013) Experimental infection of dogs with H3N2 canine influenza virus from China. Epidemiol Infect 141:2595-2603

41. Wang TT, Tan GS, Hai R, Pica N, Petersen E, Moran TM, Palese P (2010) Broadly protective monoclonal antibodies against $\mathrm{H} 3$ influenza viruses following sequential immunization with different hemagglutinins. PLoS Pathog 6:e1000796

42. Waddington CS, Walker WT, Oeser C, Reiner A, John T, Wilkins S, Casey M, Eccleston PE, Allen RJ, Okike I, Ladhani S, Sheasby E, Hoschler K, Andrews N, Waight P, Collinson AC, Heath PT, Finn A, Faust SN, Snape MD, Miller E, Pollard AJ (2010) Safety and immunogenicity of AS03B adjuvanted split virion versus non-adjuvanted whole virion $\mathrm{H} 1 \mathrm{~N} 1$ influenza vaccine in UK children aged 6 months- 12 years: open label, randomised, parallel group, multicentre study. BMJ 340:c2649

43. Martinez O, Tsibane T, Basler CF (2009) Neutralizing anti-influenza virus monoclonal antibodies: therapeutics and tools for discovery. Int Rev Immunol 28:69-92

44. de Jong JC, Palache AM, Beyer WE, Rimmelzwaan GF, Boon AC, Osterhaus AD (2003) Haemagglutination-inhibiting antibody to influenza virus. Dev Biol 115:63-73

45. Gerhard W, Mozdzanowska K, Zharikova D (2006) Prospects for universal influenza virus vaccine. Emerg Infect Dis 12:569-574

46. Bouvier NM, Lowen AC (2010) Animal models for influenza virus pathogenesis and transmission. Viruses 2:1530-1563

47. Vareckova E, Cox N, Klimov A (2002) Evaluation of the subtype specificity of monoclonal antibodies raised against $\mathrm{H} 1$ and $\mathrm{H} 3$ subtypes of human influenza A virus hemagglutinins. J Clin Microbiol 40:2220-2223

48. Matthaei M, Budt M, Wolff T (2013) Highly pathogenic H5N1 influenza A virus strains provoke heterogeneous IFN-alpha/beta responses that distinctively affect viral propagation in human cells. PLoS One 8:e56659

49. Kim HM, Lee YW, Lee KJ, Kim HS, Cho SW, van Rooijen N, Guan Y, Seo SH (2008) Alveolar macrophages are indispensable for controlling influenza viruses in lungs of pigs. J Virol 82:4265-4274

50. Fritz RS, Hayden FG, Calfee DP, Cass LM, Peng AW, Alvord WG, Strober W, Straus SE (1999) Nasal cytokine and chemokine responses in experimental influenza A virus infection: results of a placebo-controlled trial of intravenous zanamivir treatment. J Infect Dis 180:586-593

51. Hayden FG, Fritz R, Lobo MC, Alvord W, Strober W, Straus SE (1998) Loca and systemic cytokine responses during experimental human influenza A virus infection. Relation to symptom formation and host defense. J Clin Invest 101:643-649

52. Hussell T, Pennycook A, Openshaw PJ (2001) Inhibition of tumor necrosis factor reduces the severity of virus-specific lung immunopathology. Eur $J$ Immunol 31:2566-2573
53. Jung K, Lee CS, Kang BK, Park BK, Oh JS, Song DS (2010) Pathology in dogs with experimental canine H3N2 influenza virus infection. Res Vet Sci 88:523-527

54. Szretter KJ, Gangappa S, Lu X, Smith C, Shieh WJ, Zaki SR, Sambhara S, Tumpey TM, Katz JM (2007) Role of host cytokine responses in the pathogenesis of avian H5N1 influenza viruses in mice. J Virol 81:2736-2744

55. Lee YN, Lee HJ, Lee DH, Kim JH, Park HM, Nahm SS, Lee JB, Park SY, Choi IS, Song CS (2011) Severe canine influenza in dogs correlates with hyperchemokinemia and high viral load. Virology 417:57-63

56. Salomon R, Hoffmann E, Webster RG (2007) Inhibition of the cytokine response does not protect against lethal H5N1 influenza infection. Proc Natl Acad Sci U S A 104:12479-12481

\section{Submit your next manuscript to BioMed Central and take full advantage of:}

- Convenient online submission

- Thorough peer review

- No space constraints or color figure charges

- Immediate publication on acceptance

- Inclusion in PubMed, CAS, Scopus and Google Scholar

- Research which is freely available for redistribution 